\title{
STUDI TENTANG STATUS GIZI PADA RUMAHTANGGA MISKIN DAN TIDAK MISKIN
}

\author{
Hadi Riyadi'; Ali Khomsan'; Dadang S. ; Faisal A. ${ }^{1}$ dan Eddy S. Mudjajanto ${ }^{1}$ \\ ${ }^{1}$ Fakultas Ekologi Manusia,Institut Pertanian Bogor
}

\begin{abstract}
NUTRITIONAL STATUS OF POOR AND NON-POOR HOUSEHOLDS

Nutritional status is a body health condition of a person or a group of people resulting from the consumption, absorption, and utilization of nutrients in food. This study aimed to asses nutritional status of children under five years, husbands, and wives in highland and coastal areas. This study used a case control group design. Case was poor household while control group was nonpoor household. The collected data from poor and nonpoor and from the highland and coastol areas were compared. Weight was measured using digital bathscale and height uses microtoise. The results indicated that most husbands and wives were in normal category, less than $15 \%$ had low nutritional status. Prevalence of overweight occured more frequently in nonpoor households. The prevalence of nutritional problems of children under five was greater in poor households than that in nonpoor households. The children's under five years old nutritional status were similiar in both boys and girls.
\end{abstract}

Keywords: nutritional status, children, poverty

\section{PENDAHULUAN}

$\mathrm{S}$ tatus gizi merupakan keadaan kesehatan tubuh seseorang atau sekelompok orang yang diakibatkan oleh konsumsi, penyerapan (absorption) dan penggunaan (utilization) zat gizi makanan. Status gizi seseorang atau sekelompok orang dapat digunakan untuk mengetahui apakah seseorang atau sekelompok orang tersebut keadaan gizinya baik atau sebaliknya ${ }^{(1)}$.

Status gizi masyarakat dapat dicerminkan oleh status gizi pada anak usia dini (preschool)(2). Status gizi pada anak dipengaruhi oleh tiga determinan, yaitu determinan langsung, determinan tidak langsung, dan determinan dasar. Determinan langsung merupakan faktor yang terdapat pada tingkat individu, misalnya konsumsi makanan dan status kesehatan atau infeksi. Determinan tidak langsung adalah determinan yang terdapat pada tingkat rumahtangga yaitu ketahanan rumahtangga, perawatan anak, lingkungan kesehatan, termasuk akses terhadap pelayanan kesehatan. Sementara determinan dasar adalah potensi sumberdaya yang tersedia di suatu negara. Sumberdaya ini dibatasi oleh lingkungan alam, akses terhadap teknologi dan juga mutu sumberdaya sumberdaya manusia.

Berbagai penelitian menunjukkan bahwa keadaan sosial ekonomi rumah tangga menentukan status gizi anggota rumah tangga tersebut, terutama anak balita. Kemiskinan merupakan penyebab kurang gizi yang paling sering dijumpai di berbagai belahan dunia. Faktor ini harus mendapat perhatian yang serius karena keadaan ekonomi relatif mudah diukur dan berpengaruh besar pada konsumsi pangan. Masyarakat miskin di negara berkembang menggunakan bagian terbesar, sekitar 75 persen dari pendapatannya, untuk memenuhi kebutuhan pangan. Dengan terbatasnya pendapatan, pangan yang dapat dibeli juga terbatas baik jumlah maupun mutunya, sehingga konsumsi makanan juga mungkin akan rendah, selanjutnya keadaan 
gizi terganggu. Data dari Survei Sosial Ekonomi Nasional (SUSENAS) yang dilakukan oleh Badan Pusat Statistik menunjukkan bahwa semakin tinggi tingkat pendapatan semakin tinggi konsumsi energi dan protein, juga mutu makanan juga semakin baik ${ }^{(3)}$.

Penelitian ini merupakan bagian dari Studi Ketahanan Pangan dan Status Gizi Rumahtangga Miskin di Dataran Tinggi dan Rendah. Studi ini bertujuan untuk mengetahui status gizi orangtua dan balita pada rumahtangga miskin di dataran tinggi dan rendah.

\section{BAHAN DAN CARA}

Desain, Lokasi dan Sampel Penelitian

Penelitian ini menggunakan desain case-control group. Penelitian dilakukan di dua daerah yaitu Bogor (dataran tinggi) dan Indramayu (nelayan) dan masing-masing daerah diwakili oleh 3 (tiga) kecamatan. Daerah Bogor meliputi Kecamatan Ciomas, Dramaga dan Ciampea. Sedangkan di Indramayu meliputi Kecamatan Losarang, Kandanghaur, dan Sukra. Sampel kontrol adalah keluarga tidak miskin. Penelitian dilakukan selama 12 bulan yang dimulai pada November 2004 dan berakhir pada November 2005

\section{Cara Pengambilan Sampel}

Sampel keseluruhan berjumlah 751 rumahtangga dengan kriteria utama yaitu memiliki sekurang-kurangnya 1 (satu) anak balita dan memenuhi kriteria miskin atau tidak miskin menurut BKKBN. Penarikan contoh dilakukan dengan menggunakan penarikan contoh acak pada kedua lokasi penelitian. Jumlah rumahtangga di Bogor yang menjadi contoh sebanyak 375 terdiri atas 248 rumahtangga miskin dan 127 rumahtangga tidak miskin. Jumlah rumahtangga contoh di Indramayu sebanyak 376 , terdiri atas 265 rumahtangga miskin dan 111 rumahtangga tidak miskin.

\section{Data yang dikumpulkan}

Data yang dikumpulkan meliputi data sosial ekonomi rumahtangga, umur, berat badan, dan tinggi badan pada orangtua dan balita. Indeks Massa Tubuh (IMT) dihitung berdasarkan perhitungan berat badan dalam kilogram dibagi tinggi badan dalam meter kwadrat $\left(\mathrm{kg} / \mathrm{m}^{2}\right)$, dari hasil pengukuran digunakan klasifikasi menurut WHO 2001 ${ }^{(4)}$. Penimbangam berat badan menggunakan timbangan Seca dengan ketelitian 0,1 kg dan pengukuran tinggi badan menggunakan alat pengukur tinggi badan microtoise dengan ketelitian 0,1 cm. Data sosial ekonomi rumah tangga dan konsumsi makanan dikumpulkan dengan cara wawancara. Tingkat kecukupan energi dan protein dihitung berdasarkan Angka Kecukupan Gizi yang dianjurkan ${ }^{(5)}$.

\section{Pengolahan dan Analisis Data}

Pengolahan data dilakukan pada semua variabel yang tersedia. Analisis menggunakan program statistik yang diperlukan. Pendugaan parameter yang bersifat umum meliputi pendugaan nilai ratarata, simpangan baku (standar deviasi), nilai minimum, nilai maksimum bagi semua peubah kontinyu, dan proporsi bagi peubah yang kategorikal atau peubah kontinyu yang dikategorikan.

\section{HASIL DAN BAHASAN}

\section{Keadaan Umum Rumahtangga}

Rumahtangga pada penelitian ini umumnya merupakan keluarga inti dengan jumlah anggota keluarga yang kecil. Umur suami rata-rata 36 tahun di Bogor dan 34 tahun di Indramayu, sedangkan umur istri rata-rata 30 tahun di Bogor dan 29 tahun di Indramayu. Tingkat pendidikan suami dan istri di kedua wilayah penelitian umumnya adalah SD. Pekerjaan suami sebagian besar adalah pedagang untuk Bogor dan nelayan untuk Indramayu.

\section{IMT Suami}

Keadaan kurang energi kronis (chronic energy deficiency) pada orang dewasa dapat dilihat dari gambaran indeks massa tubuh (IMT) di bawah batas normal. Status gizi suami dapat dilihat pada Tabel 1 di bawah ini.

Hampir 15\% suami di Bogor tergolong kurus (thin) menurut kriteria WHO (4) dengan 
nilai IMT kurang dari $18.5 \mathrm{~kg} / \mathrm{m}^{2}$ dan yang tergolong kurus sekali (severe thin) sebesar $3,2 \%$. Di Indramayu suami yang tergolong kurus hanya $2.1 \%$ dan yang tergolong kurus sekali hanya $0.5 \%$. Prevalensi kurus (thin) di Bogor lebih rendah pada rumahtangga miskin, sedangkan di Indramayu prevalensi kurus lebih banyak pada rumahtangga tidak miskin.

Indeks massa tubuh di samping dapat digunakan untuk melihat kurang energi kronis, juga dapat digunakan untuk melihat gambaran kelebihan gizi (overweight) pada orang dewasa. Pada penelitian ini, suami selain mengalami kurang energi kronis juga ada yang mengalami overweight, yaitu $8,8 \%$ di Bogor dan $13,9 \%$ di Indramayu. Baik di Bogor maupun di Indramayu prevalensi overweight lebih banyak terjadi pada rumahtangga tidak miskin. Di Indramayu prevalensi overweight suami pada rumahtangga tidak miskin bahkan hampir dua kali lipat dibandingkan dengan prevalensi overweight pada rumahtangga miskin.

Tabel 1

Sebaran Rumahtangga menurut Status Gizi Suami (IMT)

\begin{tabular}{|c|c|c|c|c|}
\hline \multirow{2}{*}{ Katagori IMT } & \multicolumn{2}{|c|}{ Bogor } & \multicolumn{2}{|c|}{ Indramayu } \\
\hline & $\mathrm{n}$ & $\%$ & $\mathrm{n}$ & $\%$ \\
\hline \multicolumn{5}{|l|}{ Miskin } \\
\hline$<16,0 \quad$ (severe thinness) & 7 & 2.9 & 2 & 0.8 \\
\hline 16.0 - 16.99 (moderate thinness) & 3 & 1.2 & 3 & 1.1 \\
\hline $17.0-18.49$ (mild thinness) & 25 & 10.2 & 24 & 9.1 \\
\hline $18.5-24.99$ (normal) & 189 & 77.5 & 205 & 77.7 \\
\hline 25.0 - 29.99 (grade 1 overweight) & 17 & 7.0 & 28 & 10.6 \\
\hline 30.0 - 39.99 (grade 2 overweight) & 2 & 0.8 & 2 & 0.8 \\
\hline$\geq 40.0 \quad$ (grade 3 overweight) & 1 & 0.4 & 0 & 0.0 \\
\hline Total & 244 & 100.0 & 264 & 100.0 \\
\hline \multicolumn{5}{|l|}{ Tidak Miskin } \\
\hline$<16,0 \quad$ (severe thinness) & 5 & 4.0 & 0 & 0.0 \\
\hline $16.0-16.99$ (moderate thinness) & 5 & 4.0 & 3 & 2.7 \\
\hline $17.0-18.49$ (mild thinness) & 10 & 7.9 & 7 & 6.4 \\
\hline $18.5-24.99$ (normal) & 93 & 73.8 & 78 & 70.9 \\
\hline 25.0 - 29.99 (grade 1 overweight) & 12 & 9.5 & 20 & 18.2 \\
\hline 30.0 - 39.99 (grade 2 overweight) & 0 & 0.0 & 2 & 1.8 \\
\hline$\geq 40.0 \quad$ (grade 3 overweight) & 1 & 0.8 & 0 & 0.0 \\
\hline Total & 126 & 100.0 & 110 & 100.0 \\
\hline \multicolumn{5}{|l|}{ Miskin + Tidak Miskin } \\
\hline$<16,0 \quad$ (severe thinness) & 12 & 3.2 & 2 & 0.5 \\
\hline $16.0-16.99$ (moderate thinness) & 8 & 2.2 & 6 & 1.6 \\
\hline $17.0-18.49$ (mild thinness) & 35 & 9.5 & 31 & 8.3 \\
\hline $18.5-24.99$ (normal) & 282 & 76.2 & 283 & 75.7 \\
\hline $25.0-29.99$ (grade 1 overweight) & 29 & 7.8 & 48 & 12.8 \\
\hline $30.0-39.99$ (grade 2 overweight) & 2 & 0.5 & 4 & 1.1 \\
\hline$\geq 40.0 \quad$ (grade 3 overweight) & 2 & 0.5 & 0 & 0.0 \\
\hline Total & 370 & 100.0 & 374 & 100.0 \\
\hline
\end{tabular}


IMT Istri

Prevalensi kurus (thin) pada istri di Bogor sekitar $11 \%$ menurut kriteria WHO (4) dengan nilai IMT kurang dari $18.5\left(\mathrm{~kg} / \mathrm{m}^{2}\right)$ dan yang tergolong kurus sekali (severe thin) sebesar $1.6 \%$. Di Indramayu istri yang tergolong kurus hanya $9.8 \%$ dan yang tergolong kurus sekali 1.6\%. Prevalensi kurus (thin) di Bogor dan di Indramayu lebih banyak pada rumah tangga miskin dibandingkan dengan prevalensi kurus pada rumah tangga tidak miskin.

Prevalensi overweight pada istri adalah $18.4 \%$ di Bogor dan $26.7 \%$ di Indramayu. Baik di Bogor maupun di Indramayu prevalensi overweight lebih banyak terjadi pada rumahtangga tidak miskin. Di Indramayu prevalensi overweight dari rumahtangga tidak miskin bahkan mencapai $37 \%$ (Tabel 2).

Tabel 2

Sebaran Rumahtangga menurut Status Gizi Istri (IMT)

\begin{tabular}{|c|c|c|c|c|}
\hline \multirow{2}{*}{ Katagori IMT } & \multicolumn{2}{|c|}{ Bogor } & \multicolumn{2}{|c|}{ Indramayu } \\
\hline & $\mathrm{n}$ & $\%$ & $\mathrm{n}$ & $\%$ \\
\hline \multicolumn{5}{|l|}{ Miskin } \\
\hline (severe thinness) & 4 & 1.6 & 6 & 2.3 \\
\hline 16.0 - 16.99 (moderate thinness) & 7 & 2.9 & 8 & 3.0 \\
\hline $17.0-18.49$ (mild thinness) & 19 & 7.8 & 16 & 6.0 \\
\hline $18.5-24.99$ (normal) & 177 & 72.5 & 176 & 66.4 \\
\hline 25.0 - 29.99 (grade 1 overweight) & 29 & 11.9 & 49 & 18.5 \\
\hline 30.0 - 39.99 (grade 2 overweight) & 8 & 3.3 & 10 & 3.8 \\
\hline$\geq 40.0 \quad$ (grade 3 overweight) & 0 & 0.0 & 0 & 0.0 \\
\hline Total & 244 & 100.0 & 265 & 100.0 \\
\hline \multicolumn{5}{|l|}{ Tidak Miskin } \\
\hline$<16.0 \quad$ (severe thinness) & 2 & 1.6 & 0 & 0.0 \\
\hline 16.0 - 16.99 (moderate thinness) & 2 & 1.6 & 0 & 0.0 \\
\hline 17.0 - 18.49 (mild thinness) & 8 & 6.3 & 7 & 6.4 \\
\hline $18.5-24.99$ (normal) & 83 & 65.9 & 62 & 56.4 \\
\hline 25.0 - 29.99 (grade 1 overweight) & 24 & 19.0 & 32 & 29.1 \\
\hline 30.0 - 39.99 (grade 2 overweight) & 7 & 5.6 & 9 & 8.2 \\
\hline$\geq 40.0 \quad$ (grade 3 overweight) & 0 & 0.0 & 0 & 0.0 \\
\hline Total & 126 & 100.0 & 110 & 100.0 \\
\hline \multicolumn{5}{|l|}{ Miskin + Tidak Miskin } \\
\hline$<16.0 \quad$ (severe thinness) & 6 & 1.6 & 6 & 1.6 \\
\hline 16.0 - 16.99 (moderate thinness) & 9 & 2.4 & 8 & 2.1 \\
\hline $17.0-18.49$ (mild thinness) & 27 & 7.3 & 23 & 6.1 \\
\hline $18.5-24.99$ (normal) & 260 & 70.3 & 238 & 63.5 \\
\hline 25.0 - 29.99 (grade 1 overweight) & 53 & 14.3 & 81 & 21.6 \\
\hline 30.0 - 39.99 (grade 2 overweight) & 15 & 4.1 & 19 & 5.1 \\
\hline$\geq 40.0 \quad$ (grade 3 overweight) & 0 & 0.0 & 0 & 0.0 \\
\hline Total & 370 & 100.0 & 375 & 100.0 \\
\hline
\end{tabular}




\section{Status Gizi Anak Balita}

Karakteristik Antropometri Anak Balita

Rata-rata umur anak yang menjadi sampel penelitian ini adalah 2 tahun di Bogor dan 3 tahun di Indramayu. Umur anak pada rumahtangga miskin dan tidak miskin di Bogor sama, yaitu 2 tahun, sedangkan di Indramayu umur anak pada rumahtangga miskin dan tidak miskin sama-sama 3 tahun.

Rata-rata berat badan anak di Bogor adalah $12 \mathrm{~kg}$, rata-rata berat badan ini tidak berbeda antara anak laki-laki dan anak perempuan. Berat badan anak di Indramayu $13 \mathrm{~kg}$, dengan perbandingan $14 \mathrm{~kg}$ pada anak laki-laki dan $11 \mathrm{~kg}$ pada anak perempuan. Berat badan anak pada rumahtangga miskin dan tidak miskin relatif tidak berbeda.

Rata-rata tinggi badan anak di Bogor 85 $\mathrm{cm}$ dan di Indramayu $89 \mathrm{~cm}$. Pada anak lakilaki tinggi badannya sama seperti rata-rata anak keseluruhan pada kedua lokasi penelitian. Pada anak perempuan tinggi badan anak relatif sama pada kedua lokasi penelitian, yaitu $85 \mathrm{~cm}$ di Bogor dan $86 \mathrm{~cm}$ di Indramayu.

Indeks massa tubuh (IMT) anak pada kedua lokasi sama, yaitu 14, begitu pula nilai IMT antara kedua jenis kelamin (IMT 14). Nilai IMT pada anak tidak miskin 1 skor point di atas nilai IMT anak miskin.
Masalah Underweight
Masalah underweight dapat dilihat dari indikator BB/U (weight for age = W/A). Berdasarkan hasil perhitungan Z-skor BB/U dan dengan menggunakan titik batas $<-2$ sebagai underweight (4), maka prevalensi underweight pada anak balita adalah $20.7 \%$ di Bogor dan $24.5 \%$ di Indramayu. Prevalensi underweight ini sedikit lebih rendah daripada prevalensi underweight angka nasional, yaitu $27.3 \%$ (6). Prevalensi underweight, baik di Bogor maupun di Indramayu, cenderung lebih tinggi pada anak dari rumah tangga miskin dibandingkan dengan anak dari rumahtangga tidak miskin (Tabel 3).

Tabel 3

Sebaran Status Gizi Anak berdasarkan indikator BB/U

\begin{tabular}{|c|c|c|c|c|}
\hline \multirow{2}{*}{ Katagori } & \multicolumn{2}{|c|}{ Bogor } & \multicolumn{2}{|c|}{ Indramayu } \\
\hline & $\mathrm{n}$ & $\%$ & $\mathrm{n}$ & $\%$ \\
\hline \multicolumn{5}{|l|}{ Miskin } \\
\hline (underweight) & 55 & 23.9 & 58 & 25.4 \\
\hline$-2-+2$ (normal) & 171 & 74.3 & 169 & 74.1 \\
\hline$>+2 \quad$ (overweight) & 4 & 1.7 & 1 & 0.4 \\
\hline Total & 230 & 100.0 & 228 & 100.0 \\
\hline \multicolumn{5}{|l|}{ Tidak Miskin } \\
\hline$<-2 \quad$ (underweight) & 17 & 14.5 & 21 & 22.3 \\
\hline$-2-+2$ (normal) & 98 & 83.8 & 71 & 75.5 \\
\hline$>+2 \quad$ (overweight) & 2 & 1.7 & 2 & 2.1 \\
\hline Total & 117 & 100.0 & 94 & 100.0 \\
\hline \multicolumn{5}{|l|}{ Miskin + Tidak Miskin } \\
\hline$<-2 \quad$ (underweight) & 72 & 20.7 & 79 & 24.5 \\
\hline$-2-+2$ (normal) & 269 & 77.5 & 240 & 74.5 \\
\hline$>+2 \quad$ (overweight) & 6 & 1.7 & 3 & 0.9 \\
\hline Total & 347 & 100.0 & 322 & 100.0 \\
\hline
\end{tabular}


Analisis berdasarkan jenis kelamin Bogor lebih tinggi pada anak laki-laki $(24.0 \%)$ dibandingkan anak perempuan (17.6\%), sedangkan di Indramayu prevalensi antar menunjukkan prevalensi underweight di jenis kelamin relatif sama (Tabel 4 dan 5).

Tabel 4

Sebaran Status Gizi Anak Anak Laki-laki berdasarkan indikator BB/U

\begin{tabular}{|c|c|c|c|c|}
\hline \multirow[t]{2}{*}{ Katagori } & \multicolumn{2}{|c|}{ Bogor } & \multicolumn{2}{|c|}{ Indramayu } \\
\hline & $\mathrm{n}$ & $\%$ & $\mathrm{n}$ & $\%$ \\
\hline \multicolumn{5}{|l|}{ Miskin } \\
\hline (underweight) & 31 & 26.1 & 33 & 28.2 \\
\hline$-2-+2$ (normal) & 87 & 73.1 & 83 & 70.9 \\
\hline$>+2 \quad$ (overweight) & 1 & 0.8 & 1 & 0.9 \\
\hline Total & 119 & 100.0 & 117 & 100.0 \\
\hline \multicolumn{5}{|l|}{ Tidak Miskin } \\
\hline$<-2 \quad$ (underweight) & 10 & 19.2 & 10 & 18.2 \\
\hline$-2-+2$ (normal) & 41 & 78.8 & 44 & 80.0 \\
\hline$>+2 \quad$ (overweight) & 1 & 1.9 & 1 & 1.8 \\
\hline Total & 52 & 100.0 & 55 & 100.0 \\
\hline \multicolumn{5}{|l|}{ Miskin + Tidak Miskin } \\
\hline$<-2 \quad$ (underweight) & 41 & 24.0 & 43 & 25.0 \\
\hline$-2-+2$ (normal) & 128 & 74.9 & 127 & 73.8 \\
\hline$>+2 \quad$ (overweight) & 2 & 1.2 & 2 & 1.2 \\
\hline Total & 171 & 100.0 & 172 & 100.0 \\
\hline
\end{tabular}

Tabel 5

Sebaran Status Gizi Anak Perempuan berdasarkan indikator BB/U

\begin{tabular}{|c|c|c|c|c|}
\hline \multirow[t]{2}{*}{ Katagori } & \multicolumn{2}{|c|}{ Bogor } & \multicolumn{2}{|c|}{ Indramayu } \\
\hline & $\mathrm{n}$ & $\%$ & $\mathrm{n}$ & $\%$ \\
\hline Miskin & & & & \\
\hline$<-2 \quad$ (underweight) & 24 & 21.6 & 25 & 22.5 \\
\hline$-2-+2$ (normal) & 84 & 75.7 & 86 & 77.5 \\
\hline$>+2 \quad$ (overweight) & 3 & 2.7 & 0 & 0.0 \\
\hline Total & 111 & 100.0 & 111 & 100.0 \\
\hline Tidak Miskin & & & & \\
\hline$<-2 \quad$ (underweight) & 7 & 10.8 & 11 & 28.2 \\
\hline$-2-+2$ (normal) & 57 & 87.7 & 27 & 69.2 \\
\hline$>+2 \quad$ (overweight) & 1 & 1.5 & 1 & 2.6 \\
\hline Total & 65 & 100.0 & 39 & 100.0 \\
\hline Miskin + Tidak Miskin & & & & \\
\hline$<-2 \quad$ (underweight) & 31 & 17.6 & 36 & 24.0 \\
\hline$-2-+2$ (normal) & 141 & 80.1 & 113 & 75.3 \\
\hline$>+2 \quad$ (overweight) & 4 & 2.3 & 1 & 0.7 \\
\hline
\end{tabular}




\begin{tabular}{|l|c|c|c|c|}
\hline Total & 176 & 100.0 & 150 & 100.0 \\
\hline
\end{tabular}
maupun perempuan, prevalensi underweight miskin.

lebih tinggi pada anak dari rumahtangga miskin dibandingkan anak dari rumahtangga tidak miskin. Di Indramayu pada anak lakilaki, prevalensi underweight lebih tinggi pada anak miskin dibanding dengan anak tidak miskin, sebaliknya pada anak perempuan prevalensi underweight lebih tinggi pada

Jika dilihat dari Z-skor BB/U (W/A) tampak bahwa secara keseluruhan nilainya sama, yaitu rata-rata $-1,4 \pm 1,1$ di Bogor dan $1.3 \pm 1.1$ di Indramayu. Nilai Z-skor ini lebih buruk (0.1-0.3 unit SD) pada anak dari rumahtangga miskin dibandingkan dengan anak dari rumahtangga tidak miskin pada kedua lokasi (Tabel 6).

Tabel 6

Status Gizi Anak berdasarkan Indeks Status Gizi

\begin{tabular}{|l|c|c|c|c|}
\hline \multirow{2}{*}{ Indeks status gizi } & \multicolumn{2}{|c|}{ Bogor } & \multicolumn{2}{c|}{ Indramayu } \\
\cline { 2 - 5 } & Rata-rata & SD & Rata-rata & SD \\
\hline Miskin & & & & \\
BB/U atau W/A & -1.4 & 1.6 & -1.4 & 1.0 \\
BB/TB atau W/H & -1.1 & 2.4 & -1.3 & 2.3 \\
TB/U atau H/A & -0.6 & 2.9 & 0.1 & 3.2 \\
\hline Tidak Miskin & & & & \\
BB/U atau W/A & -1.3 & 1.7 & -1.1 & 1.3 \\
BB/TB atau W/H & -1.0 & 2.5 & -0.9 & 2.1 \\
TB/U atau H/A & -0.3 & 3.2 & 0.2 & 2.8 \\
\hline Miskin + Tidak Miskin & & & & \\
BB/U atau W/A & -1.4 & 1.6 & -1.3 & 1.1 \\
BB/TB atau W/H & -1.0 & 2.5 & -1.2 & 2.3 \\
TB/U atau H/A & -0.5 & 3.0 & 0.1 & 3.1 \\
\hline
\end{tabular}

Bila dibandingkan antar jenis kelamin, terlihat bahwa hampir tidak ada perbedaan nilai Z-skor antara kedua jenis kelamin (Tabel 7 dan 8). Pada anak laki-laki nilai Zskor pada anak dari rumahtangga miskin lebih buruk dibandingkan dengan Z-skor anak dari rumahtangga tidak miskin, dengan nilai perbedaan mencapai 0.2-0.6 unit SD (Tabel 7). Pada anak perempuan tidak terlihat perbedaan tersebut (Tabel 8). 
Tabel 7

Status Gizi Anak Laki-laki berdasarkan Indeks Status Gizi

\begin{tabular}{|l|c|c|c|c|}
\hline \multirow{2}{*}{ Indeks status gizi } & \multicolumn{2}{|c|}{ Bogor } & \multicolumn{2}{c|}{ Indramayu } \\
\cline { 2 - 5 } & Rata-rata & SD & Rata-rata & SD \\
\hline \multirow{2}{*}{ Miskin } & & & & \\
BB/U atau W/A & -1.4 & 1.2 & -1.4 & 1.1 \\
BB/TB atau W/H & -0.9 & 2.2 & -1.1 & 2.4 \\
TB/U atau H/A & -0.3 & 2.8 & 0.2 & 3.3 \\
\hline Tidak Miskin & & & & \\
BB/U atau W/A & -1.0 & 1.2 & -1.0 & 1.5 \\
BB/TB atau W/H & -0.4 & 2.2 & -0.6 & 2.1 \\
TB/U atau H/A & -0.2 & 2.8 & 0.2 & 2.7 \\
\hline Miskin + Tidak Miskin & & & & \\
BB/U atau W/A & -1.3 & 1.3 & -1.3 & 1.3 \\
BB/TB atau W/H & -0.3 & 2.3 & -0.9 & 2.3 \\
TB/U atau H/A & -0.3 & 2.9 & 0.2 & 3.1 \\
\hline
\end{tabular}

Tabel 8

Status Gizi Anak Perempuan berdasarkan Indeks Status Gizi

\begin{tabular}{|l|c|c|c|c|}
\hline \multirow{2}{*}{ Indeks status gizi } & \multicolumn{2}{|c|}{ Bogor } & \multicolumn{2}{c|}{ Indramayu } \\
\cline { 2 - 5 } & Rata-rata & SD & Rata-rata & SD \\
\hline Miskin & & & & \\
BB/U atau W/A & -1.2 & 1.3 & -1.3 & 0.9 \\
BB/TB atau W/H & -0.9 & 1.9 & -1.4 & 2.2 \\
TB/U atau H/A & -0.8 & 3.0 & -0.3 & 3.0 \\
\hline Tidak Miskin & & & & \\
BB/U atau W/A & -1.2 & 1.3 & -1.2 & 1.2 \\
BB/TB atau W/H & -1.2 & 1.9 & -1.0 & 2.1 \\
TB/U atau H/A & -0.4 & 3.0 & -0.7 & 2.6 \\
\hline Miskin + Tidak Miskin & & & & \\
BB/U atau W/A & -1.2 & 1.2 & -1.3 & 1.0 \\
BB/TB atau W/H & -1.0 & 2.1 & -1.2 & 2.2 \\
TB/U atau H/A & -0.6 & 3.1 & -0.4 & 2.9 \\
\hline
\end{tabular}

\section{Masalah Stunting}

Tinggi badan pada suatu waktu merupakan hasil pertumbuhan secara kumulatif semenjak lahir, sehingga dapat dipakai untuk menggambarkan riwayat gizi masa lampau. Tinggi badan juga merupakan indeks yang paling sensitif untuk mendeteksi adanya perubahan sosial ekonomi. Oleh karena itu indikator $\mathrm{TB} / \mathrm{U}(\mathrm{H} / \mathrm{A})$ dapat juga digunakan sebagai indikator keadaan sosial ekonomi. Hasil penelitian menunjukkan bahwa prevalensi stunted di Bogor sebesar $25.5 \%$ dan di Indramayu $28.0 \%$. Prevalensi stunting ini lebih rendah daripada prevalensi 
stunting nasional yang berkisar antara 30 $40 \%$. Perbandingan menurut kemiskinan menunjukkan bahwa di Bogor tidak ada perbedaan prevalensi stunted, tetapi di
Indramayu prevalensi stunted lebih tinggi pada anak dari rumahtangga miskin $(30.3 \%)$ dibandingkan dengan anak dari rumahtangga tidak miskin (22.3\%) (Tabel 9).

Tabel 9

Sebaran Status Gizi Anak berdasarkan indikator TB/U

\begin{tabular}{|c|c|c|c|c|}
\hline \multirow{2}{*}{ Katagori } & \multicolumn{2}{|c|}{ Bogor } & \multicolumn{2}{|c|}{ Indramayu } \\
\hline & $\mathrm{n}$ & $\%$ & $\mathrm{n}$ & $\%$ \\
\hline Miskin & & & & \\
\hline$<-2 \quad$ (stunting) & 59 & 25.4 & 70 & 30.3 \\
\hline$-2-+2$ (normal) & 134 & 57.8 & 96 & 41.6 \\
\hline$>+2 \quad$ (lebih) & 39 & 16.8 & 65 & 28.1 \\
\hline Total & 232 & 100.0 & 231 & 100.0 \\
\hline Tidak Miskin & & & & \\
\hline$<-2 \quad$ (stunting) & 30 & 25.6 & 21 & 22.3 \\
\hline$-2-+2$ (normal) & 62 & 53.0 & 56 & 59.6 \\
\hline$>+2 \quad$ (lebih) & 25 & 21.4 & 17 & 18.1 \\
\hline Total & 117 & 100.0 & 94 & 100.0 \\
\hline Miskin + Tidak Miskin & & & & \\
\hline$<-2 \quad$ (stunting) & 89 & 25.5 & 91 & 28.0 \\
\hline$-2-+2$ (normal) & 196 & 56.2 & 152 & 46.8 \\
\hline$>+2 \quad$ (lebih) & 64 & 18.3 & 82 & 25.2 \\
\hline Total & 349 & 100.0 & 325 & 100.0 \\
\hline
\end{tabular}

Di Bogor tidak ada perbedaan prevalensi stunted antar jenis kelamin dan antar rumahtangga miskin dan tidak miskin (Tabel 9); tetapi di Indramayu prevalensi stunted pada anak perempuan lebih tinggi (32.5\%) dibandingkan dengan anak laki-laki (24.1\%) (Tabel 10 dan 11). 
Tabel 10

Sebaran Status Gizi Anak laki-laki berdasarkan indikator TB/U

\begin{tabular}{|c|c|c|c|c|}
\hline \multirow{2}{*}{ Z-skor TB/U } & \multicolumn{2}{|c|}{ Bogor } & \multicolumn{2}{|c|}{ Indramayu } \\
\hline & $n$ & $\%$ & $n$ & $\%$ \\
\hline Miskin & & & & \\
\hline (stunting) & 30 & 25.4 & 32 & 26.9 \\
\hline$-2-+2$ (normal) & 68 & 57.6 & 50 & 42.0 \\
\hline$>+2 \quad$ (lebih) & 20 & 16.9 & 37 & 31.1 \\
\hline Total & 118 & 100.0 & 119 & 100.0 \\
\hline Tidak Miskin & & & & \\
\hline$<-2 \quad$ (stunting) & 13 & 25.0 & 10 & 18.2 \\
\hline$-2-+2$ (normal) & 28 & 53.8 & 33 & 60.0 \\
\hline$>+2 \quad$ (lebih) & 11 & 21.2 & 12 & 21.8 \\
\hline Total & 52 & 100.0 & 55 & 100.0 \\
\hline Miskin + Tidak Miskin & & & & \\
\hline$<-2 \quad$ (stunting) & 43 & 25.3 & 42 & 24.1 \\
\hline$-2-+2$ (normal) & 96 & 56.5 & 83 & 47.7 \\
\hline$>+2 \quad$ (lebih) & 31 & 18.2 & 49 & 28.2 \\
\hline Total & 170 & 100.0 & 174 & 100.0 \\
\hline
\end{tabular}

Tabel 11

Sebaran Status Gizi Anak Perempuan berdasarkan indikator TB/U

\begin{tabular}{|c|c|c|c|c|}
\hline \multirow{2}{*}{ Katagori } & \multicolumn{2}{|c|}{ Bogor } & \multicolumn{2}{|c|}{ Indramayu } \\
\hline & $n$ & $\%$ & $\mathrm{n}$ & $\%$ \\
\hline \multicolumn{5}{|l|}{ Miskin } \\
\hline$<-2 \quad$ (stunting) & 29 & 25.4 & 38 & 33.9 \\
\hline$-2-+2$ (normal) & 66 & 57.9 & 46 & 41.1 \\
\hline$>+2 \quad$ (lebih) & 19 & 16.7 & 28 & 25.0 \\
\hline Total & 114 & 100.0 & 112 & 100.0 \\
\hline \multicolumn{5}{|l|}{ Tidak Miskin } \\
\hline$<-2 \quad$ (stunting) & 17 & 26.2 & 11 & 28.2 \\
\hline$-2-+2$ (normal) & 34 & 52.3 & 23 & 59.0 \\
\hline$>+2 \quad$ (lebih) & 14 & 21.5 & 5 & 12.8 \\
\hline Total & 65 & 100. & 39 & 100.0 \\
\hline \multicolumn{5}{|l|}{ Miskin + Tidak Miskin } \\
\hline$<-2 \quad$ (stunting) & 46 & 25.7 & 49 & 32.5 \\
\hline$-2-+2$ (normal) & 100 & 55.9 & 69 & 45.7 \\
\hline$>+2 \quad$ (lebih) & 33 & 18.4 & 33 & 21.9 \\
\hline Total & 179 & 100.0 & 151 & 100.0 \\
\hline
\end{tabular}

Hasil analisis Z-skor TB/U menunjukkan bahwa nilai rata-rata Z-skor secara keseluruhan di Bogor $-0.5 \pm 3.0$ dan di Indramayu $0.1 \pm 3.1$ (Tabel 6). Nilai Z-skor 
TB/U anak dari rumahtangga miskin di Bogor lebih buruk dibanding anak dari rumahtangga tidak miskin, tetapi di Indramayu nilai Z-skor TB/U anak dari rumahtangga miskin lebih baik daripada anak dari rumahtangga tidak miskin (Tabel 8).

Nilai Z-skor TB/U menunjukkan bahwa gambarannya di Indramayu lebih baik dibanding di Bogor. Di Bogor nilai Z-skor TB/ $U$ pada anak perempuan lebih jelek dibandingkan dengan Z-skor anak laki-laki (Tabel 7 dan 8), tetapi di Indramayu gambaran Z-skor TB/U anak laki-laki lebih baik daripada anak perempuan. Pada anak laki-laki maupun perempuan, baik di Bogor maupun di Indramayu, nilai Z-skor TB/U lebih buruk pada anak dari rumahtangga miskin dibandingkan dengan Z-skor anak dari rumah tangga tidak miskin (Tabel 7 dan 8).

\section{Masalah Wasting}

Berdasarkan hasil perhitungan Z-skor indeks $B B / T B(W / H)$ dengan kriteria wasted $<-2.0 \mathrm{SD}$, ditemukan prevalensi wasted di Bogor sebesar $25.4 \%$ dan di Indramayu $35.9 \%$. Prevalensi wasting ini lebih tinggi daripada prevalensi wasting angka nasional, yaitu sekitar $15.8 \%$ (6). Apabila dibedakan menurut kemiskinan, maka terlihat bahwa di Bogor prevalensi wasting lebih tinggi pada anak dari rumahtangga tidak miskin $(31.0 \%)$ dibanding anak dari rumahtangga miskin $(22.5 \%)$, sebaliknya di Indramayu prevalensi wasting lebih tinggi pada anak dari rumahtangga miskin (41.4\%) dibandingkan dengan anak dari rumahtangga tidak tidak miskin (22.6\%) (Tabel 12).

Tabel 12

Sebaran Status Gizi Anak berdasarkan indikator BB/TB

\begin{tabular}{|c|c|c|c|c|}
\hline \multirow{2}{*}{ Katagori } & \multicolumn{2}{|c|}{ Bogor } & \multicolumn{2}{|c|}{ Indramayu } \\
\hline & $n$ & $\%$ & $\mathrm{n}$ & $\%$ \\
\hline Miskin & & & & \\
\hline$<-2 \quad$ (wasting) & 52 & 22.5 & 94 & 41.4 \\
\hline$-2-+2($ normal $)$ & 161 & 69.7 & 118 & 52.0 \\
\hline$>+2 \quad$ (lebih) & 18 & 7.8 & 15 & 6.6 \\
\hline Total & 231 & 100.0 & 227 & 100.0 \\
\hline Tidak Miskin & & & & \\
\hline$<-2 \quad$ (wasting) & 36 & 31.0 & 21 & 22.6 \\
\hline$-2-+2$ (normal) & 66 & 56.9 & 62 & 66.7 \\
\hline$>+2 \quad$ (lebih) & 14 & 12.1 & 10 & 10.8 \\
\hline Total & 116 & 100.0 & 93 & 100.0 \\
\hline Miskin + Tidak Miskin & & & & \\
\hline$<-2 \quad$ (wasting) & 88 & 25.4 & 115 & 35.9 \\
\hline$-2-+2$ (normal) & 227 & 65.4 & 180 & 56.3 \\
\hline$>+2 \quad$ (lebih) & 32 & 9.2 & 25 & 7.8 \\
\hline Total & 347 & 100.0 & 320 & 100.0 \\
\hline
\end{tabular}

Prevalensi wasting pada anak di Indramayu mencapai $41.4 \%$, suatu jumlah yang sangat tinggi. Baik di Bogor maupun di Indramayu, prevalensi wasting lebih tinggi pada anak perempuan dibandingkan dengan anak laki-laki (Tabel 13 dan 14). Apabila dibedakan menurut kemiskinan pada laki-laki dan perempuan, maka terlihat bahwa di
Bogor prevalensi wasting lebih tinggi pada anak dari rumahtangga tidak miskin, sebaliknya di Indramayu prevalensi wasting lebih tinggi pada anak dari rumahtangga miskin (Tabel 13 dan 14). Gambaran prevalensi wasting yang tinggi pada kedua daerah ini menunjukkan bahwa pada kedua 
daerah ini telah terjadi masalah kekurangan gizi akut.

Tabel 13

Sebaran Status Gizi Anak Laki-laki berdasarkan indikator BB/TB

\begin{tabular}{|c|c|c|c|c|}
\hline \multirow{2}{*}{ Katagori } & \multicolumn{2}{|c|}{ Bogor } & \multicolumn{2}{|c|}{ Indramayu } \\
\hline & $\mathrm{n}$ & $\%$ & $\mathrm{n}$ & $\%$ \\
\hline \multicolumn{5}{|l|}{ Miskin } \\
\hline (wasting) & 27 & 22.5 & 46 & 39.3 \\
\hline$-2-+2$ (normal) & 83 & 69.2 & 64 & 54.7 \\
\hline$>+2 \quad$ (lebih) & 10 & 8.3 & 7 & 6.0 \\
\hline Total & 120 & 100.0 & 117 & 100.0 \\
\hline \multicolumn{5}{|l|}{ Tidak Miskin } \\
\hline$<-2 \quad$ (wasting) & 15 & 28.8 & 12 & 22.2 \\
\hline$-2-+2$ (normal) & 28 & 53.8 & 35 & 64.8 \\
\hline$>+2 \quad$ (lebih) & 9 & 17.3 & 7 & 13.0 \\
\hline Total & 52 & 100.0 & 54 & 100.0 \\
\hline \multicolumn{5}{|l|}{ Miskin + Tidak Miskin } \\
\hline$<-2 \quad$ (wasting) & 42 & 24.4 & 58 & 33.9 \\
\hline$-2-+2$ (normal) & 111 & 64.5 & 99 & 57.9 \\
\hline$>+2 \quad$ (lebih) & 19 & 11.0 & 14 & 8.2 \\
\hline Total & 172 & 100.0 & 171 & 100.0 \\
\hline
\end{tabular}

Tabel 14

Sebaran Status Gizi Anak perempuan berdasarkan indikator BB/TB

\begin{tabular}{|c|c|c|c|c|}
\hline \multirow{2}{*}{ Katagori } & \multicolumn{2}{|c|}{ Bogor } & \multicolumn{2}{|c|}{ Indramayu } \\
\hline & $n$ & $\%$ & $\mathrm{n}$ & $\%$ \\
\hline Miskin & & & & \\
\hline$<-2 \quad$ (wasting) & 25 & 22.5 & 48 & 43.6 \\
\hline-2 - +2 (normal) & 78 & 70.3 & 54 & 49.1 \\
\hline$>+2 \quad$ (lebih) & 8 & 7.2 & 8 & 7.3 \\
\hline Total & 111 & 100.0 & 110 & 100.0 \\
\hline Tidak Miskin & & & & \\
\hline$<-2 \quad$ (wasting) & 21 & 32.8 & 9 & 23.1 \\
\hline$-2-+2$ (normal) & 38 & 59.4 & 27 & 69.2 \\
\hline$>+2 \quad$ (lebih) & 5 & 7.8 & 3 & 7.7 \\
\hline Total & 64 & 100.0 & 39 & 100.0 \\
\hline Miskin + Tidak Miskin & & & & \\
\hline$<-2 \quad$ (wasting) & 46 & 26.3 & 57 & 38.3 \\
\hline-2 - +2 (normal) & 116 & 66.3 & 81 & 54.4 \\
\hline$>+2 \quad$ (lebih) & 13 & 7.4 & 11 & 7.4 \\
\hline Total & 175 & 100.0 & 149 & 100.0 \\
\hline
\end{tabular}


Rata-rata Z-skor BB/TB di Bogor adalah - $1.0 \pm 2.5$ dan di Indramayu $-1.2 \pm 2.3$. Nilai Z-skor BB/TB, baik di Bogor maupun Indramayu, lebih buruk pada anak dari rumahtangga miskin dibanding anak dari rumahtangga tidak miskin (Tabel 6). Analisis antar jenis kelamin menunjukkan nilai Z-skor BB/TB anak laki-laki lebih baik daripada anak perempuan (Tabel 7 dan 8). Pada anak lakilaki, baik di Bogor maupun di Indramayu, nilai Z-skor BB/TB lebih buruk pada anak dari rumahtangga miskin dibanding anak dari rumahtangga tidak miskin (Tabel 7). Pada anak perempuan di Bogor, nilai Z-skor $\mathrm{BB} / \mathrm{TB}$ anak tidak miskin lebih buruk daripada anak miskin, tetapi di Indramayu nilai Z-skor BB/TB anak dari rumahtangga miskin lebih buruk daripada anak dari rumahtangga tidak miskin (Tabel 8).

\section{Faktor-faktor yang Mempengaruhi Status Gizi}

\section{Status Gizi Anak}

Hasil analisis regresi menunjukkan bahwa peubah yang berpengaruh secara signifikan terhadap status gizi balita berdasarkan berat badan menurut umur ( $Z$ $\mathrm{BB} / \mathrm{U})$ adalah tingkat kecukupan konsumsi protein dan pendapatan rumahtangga perkapita $(\alpha=0.05)$. Semakin tinggi tingkat kecukupan protein atau semakin tinggi pendapatan semakin tinggi pula status gizi balita. Namun demikian kedua peubah bebas tersebut hanya mampu menjelaskan keragaman Z BB/U sebesar 2.03\%.

Berdasarkan hasil analisis regresi, pada $a=0.05$ ternyata peubah-peubah tingkat kecukupan protein, tingkat kecukupan energi, pendidikan suami, pendidikan istri, pendapatan rumahtangga, jumlah anggota rumahtangga, umur suami, umur istri, dan tingkat kemiskinan belum menunjukkan pengaruh terhadap status gizi anak berdasarkan Berat Badan menurut Tinggi Badan (Z BB/TB) ataupun terhadap status gizi berdasarkan Tinggi Badan menurut Umur (Z TB/U). Hal ini mungkin karena Z BB/ TB atau $Z$ TB/U merupakan gambaran status gizi masa lampau, sementara nilai-nilai peubah bebas yang dijadikan penduga variabel hanya menunjukkan rekaman waktu yang lebih singkat.

\section{Status Gizi Suami Istri}

Peubah yang berpengaruh sangat nyata ( $a=0.01$ ) terhadap status gizi menurut Indeks Massa Tubuh Suami (IMTS) adalah Tingkat Kecukupan Protein (TKP), Umur Suami (US), Pendidikan Suami (PS), dan kategori rumahtangga. Semakin tinggi tingkat kecukupan protein, semakin tinggi pendidikan suami, semakin tua suami, maka semakin tinggi pula status gizi suami. Koefisien kategori rumahtangga K1 menunjukkan bahwa rumahtangga petani miskin memiliki status gizi terendah. Tidak ada perbedaan status gizi suami antara rumahtangga tidak miskin petani, miskin non petani dan tidak miskin non petani. Namun demikian keempat peubah bebas tersebut hanya dapat menggambarkan $4.41 \%$ dari keragaman status gizi.

Peubah yang berpengaruh secara nyata terhadap Indeks Massa Tubuh Istri (IMTI) adalah Tingkat Kecukupan Protein (TKP), Umur Suami (US), dan kategori rumahtangga (K1, K3). Semakin tinggi Tingkat Kecukupan Protein, semakin tua suami maka semakin tinggi IMT Istri. Istri rumahtangga miskin memiliki IMT lebih rendah daripada istri rumahtangga tidak miskin. Namun demikian, keempat peubah tersebut hanya dapat menjelaskan keragaman IMT istri sebesar $6.22 \%$.

\section{Ciri-ciri Rumahtangga dengan Anak Stunted}

Hasil penelitian menunjukkan bahwa ciri rumahtangga anak stunted yang pertama adalah pendapatan yang lebih rendah. Ciri kedua adalah pengeluaran pangan yang lebih rendah. Ciri ketiga status gizi berdasarkan z-skor TB/U yang lebih buruk (negatif). Berdasarkan ciri tersebut terlihat bahwa anak stunted sangat erat kaitannya dengan keadaan ekonomi. 
Ciri-ciri Rumahtangga dengan Anak Underweight

Ciri rumahtangga anak underweight yang pertama adalah pengeluaran pangan yang lebih rendah. Ciri kedua adalah indeks massa tubuh (IMT) suami dan istri yang lebih rendah. Ciri ketiga adalah status gizi berdasarkan z-skor BB/TB yang lebih buruk (negatif). Ciri keempat adalah intik energi dan zat gizi yang lebih rendah. Oleh karena itu dapat disimpulkan bahwa ciri-ciri rumahtangga yang anaknya mengalami underweight sangat terkait dengan keadaan ekonomi dan akses terhadap pangan.

Ciri-ciri Rumahtangga dengan Anak Wasted

Ciri rumahtangga anak wasted yang pertama adalah pendapatan yang rendah. Ciri kedua adalah pengeluaran pangan yang rendah. Ciri ketiga adalah indeks massa tubuh (IMT) istri yang lebih rendah. Ciri keempat adalah status gizi anak berdasarkan z-skor BB/U yang lebih rendah. Oleh karena itu dapat disimpulkan bahwa anak wasted sangat erat kaitannya dengan keadaan ekonomi yang rendah dan IMT istri yang juga relatif rendah.

\section{KESIMPULAN}

Hampir $\quad 15 \%$ kepala keluarga (ayah) dan 11\% ibu di Bogor status gizinya tergolong kurus (thin; IMT $<18.5$ ), sedangkan di Indramayu sekitar $10.4 \%$ kepala keluarga (ayah) dan $9.8 \%$ ibu tergolong kurus (thinness). Di samping mengalami kekurangan gizi, para orangtua juga mengalami kelebihan gizi (overweight; IMT >25.0), dengan prevalensi overweight pada kepala keluarga (ayah) 8,8\% di Bogor dan $13.9 \%$ di Indramayu serta prevalensi overweight pada ibu $18.4 \%$ di Bogor dan $26.7 \%$ di Indramayu. Prevalensi overweight ini lebih banyak terjadi pada rumahtangga tidak miskin.

2. Masalah gizi pada anak balita masih relatif tinggi, hal ini terlihat dari prevalensi underweight, stunting dan wasting; di Bogor masing-masing
$20.7 \%, 25.5 \%$, dan $25.4 \%$ serta di Indramayu masing-masing $24.5 \%$, $28.0 \%$ dan $35.9 \%$. Masalah gizi pada anak balita ini prevalensinya lebih besar pada anak balita dari rumahtangga miskin dibanding anak balita di rumahtangga tidak miskin. Masalah gizi anak balita hampir tidak berbeda antara anak laki-laki dan perempuan.

\section{UCAPAN TERIMA KASIH}

Peneliti mengucapkan terima kasih dan apresiasi kepada Neys von Hoogstraten Foundation (NHF) Belanda selaku penyandang dana penelitian atas kesempatan yang telah diberikan sehingga penelitian ini dapat dilaksanakan.

\section{RUJUKAN}

1. Nasoetion, A \& H. Riyadi. Gizi Terapan. Departemen Gizi Masyarakat dan Sumberdaya Keluarga. Fakultas Pertanian. Institut Pertanian Bogor. 1994.

2. Suhardjo.Indonesian Nutritional Status and Desirable dietary Pattern. Indonesian Food Journal, No. 4 Vol. 11. 1991.

3. Martianto, D. dan Ariani, M. Analisis Perubahan Konsumsi dan Pola KonsumsiPangan Masyarakat dalam Dekade Terakhir. Dalam Prosiding Widyakarya Nasional Pangan dan Gizi VIII: Ketahanan Pangan dan Gizi di Era Otonomi Daerah dan Globalisasi. Jakarta: LIPI. 2004

4. WHO. Physical Status: The Use and Interpretatiton of Anthropometri. Report of a WHO Expert Committee. World healt organization, Geneva. 1995.

5. Widya Karya Nasional Pangan dan Gizi VIII. Jakarta: LIPI.2004.

6. Depkes RI. Gizi dalam Angka Sampai tahun 2002. Jakarta: Depkes RI.2003.

7. Atmarita dan Fallah, T.S. Analisis Situasi Gizi dan Kesehatan Masyarakat. 
Dalam Prosiding Widyakarya Nasional Pangan dan Gizi VIII: Ketahanan Pangan dan Gizi di Era Otonomi Daerah dan Globalisasi. Jakarta: LIPI. 2004 